\title{
GOLGONA ANGHEL. DO REALISMO SATÍRICO À POÉTICA VADIA
}

\author{
GOLGONA ANGHEL. FROM SATIRICAL \\ REALISM TO VAGUE POETICS
}

\author{
Daniel de Oliveira Gomes ${ }^{1}$
}

\begin{abstract}
RESUMO
Abordaremos o livro "Vim porque me pagavam" de Golgona Anghel. Nesta autora, queremos observar precisamente a característica transfronteiriça da identidade prostituível do presente e questões daquilo que podemos notar como sendo seu "realismo satírico", onde a autora inspira-se na tradição burlesca lusitana.
\end{abstract}

PALAVRAS-CHAVE: Golgona Anghel; realismo satírico; poesia contemporânea

\section{ABSTRACT}

We will approach Golgona Angel's book "Vim por que me pagavam”. In this author, we want to observe precisely the characteristic of the prostituted identity of the present and questions of what we can notice as its « satirical realism », where the author is inspired by the Lusitanian burlesque tradition. KEYWORDS: Golgona Anghel; satirical realism; contemporary poetry 
No presente texto, trabalharemos o livro "Vim porque me pagavam" de Golgona Anghel, poetisa atual que, apesar de nascida na Romênia, escreve em português sendo residente em Portugal há muito tempo, onde estudou e foi autora da tese de doutoramento "A Metafísica do Medo" sobre o poeta Al Berto, defendida na Faculdade de Letras da Universidade de Lisboa. Nesta autora, queremos observar precisamente a característica transfronteiriça da identidade prostituível do presente e a projetividade do que aqui pontuaremos - um tanto quanto desenquadradamente, ou dissonantemente como "realismo satírico" e que adviria na verdade como uma reatualizarão da velha tradição burlesca lusitana, ancorada em muitos autores, dentre os quais, sobremodo a nosso ver, Cesário Verde. ${ }^{2}$ Independentemente de ela ter nascido na Romênia, quero percebê-la tendo Portugal como casa $\left(\right.$ bordel $\left.^{3}\right)$ e a língua portuguesa como seu referencial de origem (putopoética ${ }^{4}$ ). E o mote da subjetividade transfronteiriça em casos biográficos da poesia lusitana não é em nada novo, tendo suas raízes já na hibridez identitária moderna, por exemplo, de Fernando Pessoa (português de sangue judeu educado em inglês na África do Sul).

Golgona, uma trovadora estrangeira diferenciada, ou quase es-

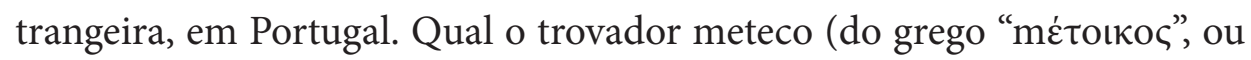
seja, aquele que já na Grécia clássica estava "quase em meio" à sociedade ateniense, da nação; o migrante aproximadamente identificado com o novo local). Tomo a cercania com o uso do termo "meteco" pelo professor André Queiroz que, em entrevista a Ney Ferraz Paiva, proporá o escritor "meteco" como um estrangeiro diferenciado, um gago na língua outra, sua quase-escolha, seu quase-topos, o ser das esquinas, "aquele que está envolto pelos traços de uma cultura que não é sua, por uma língua que não é sua, por uma história que não lhe pertence(...)” (QUEIROZ, 2013, p.186). Golgona é uma metéca lusitana 5 .

Tentar desnovelar o jogo de influências de um/uma poeta desterritorializada por excelência ${ }^{6}$ é uma missão dificílima e jamais seria o caso, aqui agora. Antes de qualquer coisa, vale observar que a extensão estilística possível do inaugurador da poesia realista do cotidiano em Portugal é uma hipótese que pode se validar não sendo por leitura direta, em Golgona Anghel, mas talvez, em rebote de leituras influentes da obra al bertiana por parte da poetisa que o estudou profundamente (a Al Berto). Está-se clara a possibilidade de ressonância de $\mathrm{Al}$ Berto na autora. ${ }^{7}$ Note-se, por exemplo, o poema abaixo, de $\mathrm{Al}$ Berto, constante em Horto de Incêndio:

Desejaste um país de silêncio

De chuvas salgadas - sem caminhos nem sonhos

Tiveste um país sombrio

Onde a realidade devorou o delírio e

Ficou desabitado - este país nocturno que geme

Contra a solidão do corpo - perguntas-te

Que espécie de lume cospem os cardos?

Caberá o mar dentro da tua ausência? E o caule 
Negro dos analgésicos por mim acima... que cidade

De areia construída grão a grão aparecerá?

Quantas lisboas estarão enterradas? Ou submersas?

(AL BERTO, 1997, p. 43)

A ideia de uma Lisboa subjetivamente submersível tão constante em "O Sentimento de um Ocidental", ou, no caso de Cesário, submersa paulatinamente no espaço do silêncio, no esquadrinhamento vazio da modernização, no vale escuro das muralhas da pluralidade, nas horas mortas. $\mathrm{O}$ início e o findar de um dinamismo angustiante. Já Al Berto pluraliza e minimiza Lisboa, propondo "lisboas" que são muitas, enterradas ou submersas. O delírio lúcido de Cesário Verde perdeu para a força da realidade, conforme Al Berto, e é esta ausência/falha de delírio, ou este delírio perdido, que povoará a poesia de Golgona Anghel, como veremos, quer seja, uma poesia onde não há nem mais lisboas, há apenas o poeta vendível, ilocalizável em um mundo sem estranhamentos já na ordem capital e coletiva do delírio (econômico, virtual, evolutivo). Em Golgona, pinceladas pós-cinemáticas, vadias, de um mundo comercializado em forma-imagem mutante prostituto onde rege "o vazio da web e o mal estar das massas" (ANGHEL, 2011, p.49). Afinal, como expõe seu verso: "Encontrar-te-ás sozinho à porta do delírio." (ANGHEL, 2011, p.46)

Por mais que sejam atitudes muito distintas de produção poética, constam vários pontos de encontro causais entre $\mathrm{Al}$ Berto, Cesário Verde e Golgona Anghel, mas não procurarei, aqui, fazer um inventário total e protocolar, apenas sugiro alguns pontos bem genéricos tais como: a solidão do olhar; o caos íntimo como superior ao caos social; o narcisismo dissonante; a valorização de detalhes circunstanciais... E haveria pontos de distinção também: pontuar-se-ia algo no que tange a questão sonora como o fato de Golgona Anghel, em sua convergência em tese mais "realista", demonstrar-se, quem sabe, menos lírica ou "musical", ou seja, estar menos à caça declamativa de uma voz, como fora em Al Berto.

É possível pensarmos ainda nos diferentes horizontes de expectativa implicados em cada poética: a primeira, to be studied, é cerebral, rigorosa; a outra, to be declaimed, é sensitiva, marginal. Al Berto tendia claramente para o segundo grupo, como confidencia em entrevista televisiva de 1994 - transcrita por Golgona Anghel: "Há um momento em que me sinto quase compelido a ler as coisas em voz alta e leio e mesmo acontece de gravá-los para depois me ouvir". Sobre isso, como bem pontuou Anghel, havia na poesia de Al Berto a exigência de uma voz. (SASAKI, 2013, p.44)

O que estou a achar observar é a possível especificidade transfronteiriça própria de Golgona Anghel, de modo mais imanente, caso esta especificidade exista, bem como os momentos onde ela apenas parece retinir al bertianamente certos temas repercussivos. Quero ponderar a dissimetria de contexto em que escreve a poeta e que lhe serve de alicerce, a coerção ritual do presente. Um presente, uma contemporaneidade, onde os poetas 
despontam vendíveis ante um jogo editorial de expectativas preestabelecidas que exige sempre um fazer inventivo estrito, uma "voz marginal" (capaz de lembrar o "cânone dos marginais", de acompanhar o valor de rebeldia já sedimentado na história), mas que, em contrapartida, inclua alguma incidência pós-vanguardista com a sujeição virtual, coletiva, do presente, algo capaz de ainda colidir com o esperado, chocar um público de modo diferente (ou ao ponto de vender a "sua" ideia). E o problema do revelar pessoal, da revelação da voz própria pela poesia, está aí. Reflito, tal como já apontava Foucault, em A Ordem do Discurso, no fato de que não há, aparentemente, mais as velhas sociedades de discurso no sentido do jogo ambíguo do segredo e da divulgação, como antigamente. Porém, ainda se manifesta uma força coercitiva no sistema de institucionalização de uma obra, um código de edição, um estilo moderno, uma constituição de personagem-escritora, uma demarcação de singularidades esperadas (próximas aos problemas ou questões do presente). Também, assim sendo, percorremos como isto tudo afeta sua produção enquanto substância assimilável por um tom marginal preestabelecido e o seu ensaiar enquanto fenômeno autoral do presente.

Jean Baudrillard, catastrófico, anti-foucaultiano, por sua vez expõe o narcisismo do contemporâneo, em sua dissonância dos simulacros, ou melhor, a autoreferência perdida de um mundo implodido à pura poeira técnica e superficialismo designativo, um urbanismo púbere do excesso informacional e do deslumbramento publicitário, onde a virtualização de tudo, pelas tecnologias do virtual, exterminaram toda dimensão política possível. O sociólogo francês articularia que "é inútil procurar uma política do virtual, a ética do virtual, etc., dado que a própria política torna-se virtual." (BAUDRILLARD, 2005, p.75). Nisso, inclui-se também a política do poético. Nisso, é possível garimpar a característica latente de um tom narcísico e político-virtual ou apolítico, ou ainda "transpolítico", melhor dizendo, próprio deste nosso tempo em que Golgona escreve, onde o virtual nos pensa e não o inverso, coisa já antessentida como apocalipse, histerismo, extemporaneidade, das paisagens citadinas individualistas na poesia de Cesário ou nos lapsos-vestígios de outros tempos da poesia al bertiana. Para mim, seduzindo seu leitor, nesta esquina, neste canto, está Golgona ecoando o simulacro. O realismo coletivo e o narcisismo do real; a busca de uma voz e a afasia do presente; a referência da literatura canônica lusitana e a singularidade al bertiana e/ou da poesia marginal narcísica de algumas décadas atrás. Como diz Emerson da Cruz Inácio, em seu livro teórico sobre Al Berto, A Herança Invisível. Ecos da Literatura viva na poesia de Al Berto: "Al Berto escreve porque precisa dar voz ao Narciso que tem dentro de si” (CRUZ INÁCIO, E., 2009, p.115). Não queremos, aqui, julgar a degenerescência política do presente, como o faz Baudrillard, em termos sociológicos, não é o caso, fiquemos no plano da estética poética. Todo modo, penso que a subjetividade em deriva ao mesmo tempo em que se sustenta o narcisismo (a autoreferência perdida) acabaria sendo o liame condutor destes poetas, se quiséssemos aproximá-los, apesar de tantas incompatibilidades existentes: Golgona Anghel; Al Berto e Cesário Verde. A real esquina dos dramáticos vadios. 
Uma característica que, muitas vezes, aparece no realismo de Cesário Verde é a descrição do feminino de modo satírico (coisa que tentarei, logo adiante, mostrar na primeira poesia do livro de Golgona Anghel) como vemos nos versos finais do soneto "Proh pudor!" que expõem: "Todas as noites ela, ah!, sordidez!/Descalçava-me as botas, os coturnos,/ E fazia-me cócegas nos pés..." (VERDE, 2006, p.47). Estes versos cesarianos designam um efeito de grande irreverência ao final do soneto que criava toda uma expectativa fantasiosa, envolto em alto lirismo, repetindo que todas as noites "ela o cingia", todas as noites "uma fantasia" entre o casal, todas as noites ela tinha um "furor dos mais soturnos", e este furor era relacionado, no final das contas, a nada de impertinente que pudesse ser imaginado pelo leitor e, sim, um mero fetiche às botinas, "os coturnos", os pés, do amante. A irreverência, ou a insolência, associada ao feminino é uma característica clássica da literatura portuguesa, e se fossemos buscar uma genealogia hipotética no gênero poético, cairíamos em referenciais muito mais ácidos desde as cantigas trovadorescas de escárnio e maldizer da lírica galego-lusitana. Dentre outros, Golgona Anghel citará em "Vim porque me pagavam", repetidamente, ao novelista florentino do século XIV, Boccaccio, autor das novelas satíricas do Decameron.

Para sugerir uma imagem realista do elemento feminino pintado satiricamente, vale lembrar a descrição inicial da personagem clássica do realismo português, Juliana, de $O$ Primo Basílio. ${ }^{8}$ Não é gratuitamente que citamos esta personagem queiroziana. É que Golgona Anghel refere-se diretamente a ela, bem como a Eça de Queiroz. Dirá, no final de sua primeira poesia: "Ó Juliana Couceiro Tavira, per omnia saecula, chaga para cá a garrafa e o cinzeiro; temos assuntos por tratar e meia hora de critérios." (ANGHEL, 2011, p.9). Utilizando a expressão latina "para todo o sempre" (per omnia saecula), invita a personagem vilã como parceria em seu juízo crítico ("meia hora de critérios"), reforçando sua clássica presença no imaginário ficcional português, reenfatizado ainda mais pela interjeição "Ó" (Um vocativo, aqui, mas que também se enreda sonoramente à interjeição também latina "Oh") antes do nome próprio da protagonista Juliana Couceiro Tavira ${ }^{9}$. A personagem feminina chantagista e oportunista de Eça que faz contraposto extremo - e, para parte da crítica de Eça, um contraposto altamente caricato - à outra protagonista, Luísa, a patroa romântica, cheia de fantasias, a idealista, a amante. “(...) O feitio da botina, a mania, a despesa,/ o cheiro a terebintina./ Ó Juliana couceiro/ Tavira, per omnia saecula,/ chega para cá a garrafa e o cinzeiro;/ temos assuntas por tratar e meia hora de critérios" (ANGHEL, 2011, p.8). De tal modo, Golgona inicia o seu Vim porque me pagavam, lançado em 300 exemplares pela Mariposa Azual, com um poema aparentemente casual, com referências a clássicos, cânones intelectuais, cinemáticos, a escritores, poetas, espaços franceses, como virá a ser sua característica mesma em outros poemas. Mas, a primeira impressão do leitor é a da suscitação de uma sátira ainda não bem desvelada. A escritora avacalha-se ou goza-se? O que estará tal poeta propondo, exagerando, exacerbando, desde o cair de paraquedas na convocação de uma vilã clássica do realismo lusitano ${ }^{10}$ ? 
O leitor jaz ante uma poetiza que se identifica caricaturalmente com a engomadeira clássica satirizada pela ficção lusa, ou seja, não está diante de uma poetiza inconsciente de que sua obra dá-se como "um dever doméstico aos prazeres da sociedade", mas sim diante do "arzinho de provocação e de ataque" (ANGHEL, 2011, p.7), que está em personagens como Juliana, de Eça. É uma autosabotagem, penso, uma sátira poético-autoral imediata, ao encalço do autoescárnio não muito comum em poesia lusitana contemporânea. E as várias pistas desta identificação do eu-lírico com o adverso, o avesso da representação heróica, o perfil antagônico e repleto de contrariedades de um personagem autoral que se imposturará vilão, vendível, a partir da poesia provocativa e dessublimativa, tal como dirá Golgona, "porque escrever não é só abrir cabeças com o bisturi de Lacan, e porque um poema não é Isabella Rossellini a chorar todos os sábados à noite" (ANGHEL, 2011, p.7). ${ }^{11}$ Ao contrário, Golgona engoma uma poesia sanguessuga da velha sátira (característica típica da subjetividade lusitana tal como apontada por Jacinto do Prado Coelho) que nos provoca aridamente situando a si mesma na dimensão da infelicidade, da miséria, da desventura feminina ante seus mitos, poesia assim em nada heroica, também, "coitada, coitadinha, coitadíssima”, poeta consciente de que caminha em uma mísera sociedade contemporânea de deposição do cânone literário, cujos passos se darão, portanto, como se em pés apertados por botinas de ponteiras de verniz (como descreveria Eça) ou "pés para andar nos corredores da ONU, o feitio da botina, a mania a despesa" (ANGHEL, 2011, p.8). A metapoesia que se abanca, então, como contratempo vadio, que permanece no decurso de contrariedades em contrariedades.

Esta característica de uma cruel arrogância, de um desdém solene pelo seu próprio tempo, remetendo a outro tempo, o que já é reminiscência bem batida de muitos poetas da poesia portuguesa moderna, e que observávamos desde, por exemplo, Cesário Verde. Recordemos de "Contrariedades". ${ }^{2}$ Desatento como herói de lutas ideológicas, Cesário Verde oscila entre a raiva individualista pelos jornalistas medíocres que odeiam seus alexandrinos (figurados aqui por “Zacone”, jornalista mediano da época) e a piedade pela pobre engomadeira tísica e faminta, a quem espia pela janela. De certa perspectiva, Cesário larga-se entre paisagens do seu próprio processo escritural, sua bios-grafia, seu desabafo metalinguístico, seu desdém pela imprensa medíocre, a coterie odiosa, criticando a crítica, a recepção de sua obra, numa época de leitores plangentes e jornais que lhe rejeitam a produção. De outro lado, olhando sob o prisma de sua hipersensibilidade individualista, está a "engomadeira", incidindo outra vez na característica negativa da mulher, do seu público, o novo público feminino da modernidade a ser criticado baudelairianamente, a decepção por sua recepção, os órfãos, digamos, os "tísicos" da modernidade. Aqueles que oram por receber uma moeda caída.

E a tísica? Fechada, e com o ferro aceso!

Ignora que a asfixia a combustão das brasas,

Não foge do estendal que lhe humedece as casas, 
E fina-se ao desprezo!

E estou melhor; passou-me a cólera. E a vizinha?

A pobre engomadeira ir-se-á deitar sem ceia?

Vejo-lhe a luz no quarto. Inda trabalha. É feia..

Que mundo! Coitadinha! (VERDE, 2006, s/p.)

A invalidação do puritanismo da musa devaneadora clássica, ou melhor, a exaltação da musa engomadeira, de fora, arredada, a observada de dentro de casa, a musa digna de se pensar "coitadinha", com fome, doente, laboriosa, aquela a quem se deve um cinismo piedoso próprio de um olhar cítrico, afiado e anti-moderno como o era o de Cesário Verde. Por outro lado, paradoxalmente, postulando uma poesia ainda universal, Golgona, mais de um século depois, não vem propiramente a se constituir anti-moderna - pois subjetivamente um século depois enfrentamos outra modalidade de crises, distinta daquela da revolução moderna que deflagrava na estabilização das imagens, onde não temos mais as antigas referências de constância, a criticar pontualmente - ao contrário, ela reflete o personalismo presente da pós-modernidade (onde o próprio escritor é, agora, a engomadeira), mas se assentando, ela mesma, como esta "outra musa", a leitora, por vezes pobre, vendida, puta, estrangeirada, por vezes aparentemente megalomaníaca (porque não está do lado "de lá" da janela do escritório).

E vai pondo, a título de exemplo que "já fui cigana, já fui puta” (ANGHEL, 2011, p.13); outras vezes que "escrevo muito porque eu sei que, ao fim de mil páginas, haverá sempre algum crítico a comparar-me com Proust." (ANGHEL, 2011, p.16). Noto, assim, que a estratégia irreverente, oposta à angústia do desreconhecimento cesariano, parece ser a de sempre autopostular-se, de modo egóico e instável, como ser comum e despojado, um autor/leitor comum, acima (ética ou esteticamente) da crítica possível de seu tempo, e não mais na posição infra-crítica, a do poeta não reconhecido. O valor a buscar não importa mais. Algumas poucas moedas caídas já serão o suficiente. Destarte, vai dizer, ao término da primeira parte de seu livro, intitulada 'Sem Destino': "Obrigado por terem vindo cá para me beijarem o anel” (ANGHEL, 2011, p.26), definindo seu rendar de versos como apenas "um croché esquecido em cima do refrigerador" (ANGHEL, 2011, p.25). Então, uma micropoesia pretenciosa (ou mesmo arrogante, andarilha, vendível) dá lugar às grandes e velhas poesias universais, aparentemente despretenciosas, contudo "valorosas", fixadas na audácia contra a crítica, moralmente oculares. "Penso em ti como se me permitisse a arrogância ${ }^{13} /$ de escrever uma crítica sobre um filme que não vi” (ANGHEL, 2011, p.38). Afinal, a poesia de Golgona advém de um contexto transnacionalizado, um tempo pós-utópico, onde “(...) as durações chegam-me nebulosas e aleatórias, ilhas de silêncios, actos falhados” (ANGHEL, 2011, p.38) e, também, em outro pressuposto urbano, ou pós-urbano como queiram, onde a crise contemporânea, no sentido espacial, passa a ser, agora, a "crise das referências", aonde as aparências instáveis suplantam as imagens estáveis da modernidade tardia, ou, remeto a Paul Virilio: 
Se é possível falar em crise, hoje em dia, esta é, antes de mais nada, a crise das referências (éticas, estéticas), a incapacidade de avaliar os acontecimentos em um meio em que as aparências estão contra nós. O desiquilíbrio crescente entre a informação direta e a informação indireta, fruto do desenvolvimento de diversos meios de comunicação, tende a privilegiar indiscriminadamente toda informação mediatizada em detrimento da informação dos sentidos, fazendo com que o efeito de real pareça suplantar a realidade imediata. A crise das grandes narrativas da qual nos fala Lyotard denuncia aqui o efeito das novas tecnologias, que enfatizam mais os 'meios' do que os 'fins'. (VIRILIO, 1999, p.18)

A questão do sentimentalismo conjunto a um esgotamento do lirismo, da pena poética com que Cesário observa as mulheres, mesmo as varinas do clássico "O Sentimento de um Ocidental”, usualmente tido como seu principal poema, esta questão sentimental está de modo avesso em Golgona, voltada, muito mais narcisicamente, a si mesma, sua condição anestésica de poeta: "porque eu sei que, mesmo habitando a cidade dos imortais, há um rio algures que nos devolve a mortalidade e tenho pena que me tenha calhado beber dessas águas" (ANGHEL, 2011, p.19). Versos apreciáveis, no sentido realista da produção, que, por vezes, também esteiam o desejo da simplicidade, uma simplicidade de superfície (herdeira superficial da singeleza de Al Berto), de se ser alguém comum, de se tentar ser alguém feliz, postulando aí o reino literário como um reino de abatidos, quem sabe, como nestes versos de "Poeta na Praça da Alegria":

Não sou infeliz. Não, não me quero matar./ Tenho até uma certa simpatia por esta vida/ passada nos autocarros,/ para cima e para baixo./ Gosto das minhas férias/ em frente da televisão./ Adoro essas mulheres com ar banal/ que entram em directo no canal./ Gosto desses homens com bigodes e pulseiras grossas./ Acredito nos milagres de Fátima/ e no bacalhau com broa./ Gosto dessa gente toda./ Quero ser um deles. (ANGHEL, 2011, p.25)

A poeta, por sua vez, prosseguindo na herança burlesca, pelo soslaio do autodesdém, desta tendência à dessubjetivação da realidade objetiva, e no mesmo gosto do pintar satírico do elemento feminino, será uma espécie de flaneur feminino dessubjetivo da escritura na era da pós-modernidade. A poeta que veio porque a pagavam, tal como "essas mulheres com ar banal", ela, a que já ocupou todos os lugares, peregrina, vagante, cigana, puta. "Já falei de Drácula que chegue./ Já apanhei morangos na Andaluzia./ Já fui cigana, já fui puta" (ANGHEL, 2011, p.13). Ou então: "Vou esvaziando os copos/ e começo a compilar beijos, / como quem junta, à pressa, moedas caídas pelo chão:/ somos todas putas, rapaz,/ com ou sem vodka." (ANGHEL, 2011, p.52).

Uma poeta que produz como quem junta, à pressa, moedas caídas, ou seja, uma colecionista observadora de indiscrições e valores preeminentemente do tempo presente; uma acumuladora ex/citada das sensações de 
desejos e de insatisfações que se sequencializam incessantemente, nesta era global em que impera o jogo do consumidor indócil, impaciente, impetuoso (figura que conforme Bauman advém no impulso de satisfação aventureira, em geral, muito mais promovida no consumo de sensações do que no aparente consumo de coisas, objetos).

Se Cesário mostrava certa inquietude em uma sociedade de produção de fase industrial, minando despropositadamente os escopos burqueses que os câmbios técnico-urbanos impunham à civilização, ao seu tempo, Golgona, em uma sociedade de consumo, de volatilidade subjetiva - ao que Félix Guatarri chamaria de "desterritorialização subjetiva”, por exemplo -de um modo também neurotizantemente individualista, Golgona trabalha a fragmentação do sujeito pós-utópico, propondo suas impressões velozes (influência de Cesário?). Ou, diríamos, impressões velozes da ondulação emocional ou da anestesia da pressão subjetiva que, em tese, produz um autor incompreendido ou aceito socialmente. Sob uma era em que aquilo que Italo Calvino nominava como "o cânone" vai conservar-se paradoxalmente como produto, em quão intenso máquinário editorial de produção de novos mitos literários, em rítmo frenético, quando já não temos mais tantos hábitos de valor, ou melhor, quando vamos substituíndo nossos hábitos por meta-hábitos, hábitos de mudar de hábitos, diria Zigmunt Bauman. A descartabilidade abrolha aí como aquilo que toma lugar a um futuro que não se pode mais comprar a prestações. "Vim porque me pagavam, e eu queria comprar o futuro a prestações” (ANGHEL, 2011, p.58).

Eis uma vinda que procura seu lugar na colheita, em um campo (o poético). Campo de produção de livros-produtos, sem excessos espirituais ou romantismos, regado com o tom burlesco que alude ao pragmatismo comercial, buscando um retorno artesanal opositivo às produções mecânicas da indústria editorial. A poesia lusitana é se sempre foi tão rica, tão brilhante, ofuscante, como sabemos, que marcar uma diferença no presente é marcar uma diferença entre preciosidades, entre pedras preciosas já lapidadas pela história e pela crítica, ou seja, é não ser mais um diamante, e é, neste caso, propor uma poesia vadia, quase bruta, banalidade de uma poesia da esquina que qualquer produtor produziria. Lembro de uma passagem, que leio como metaliterária, de Gonçalo M. Tavares, em O Senhor Brecht, que diz: "Em vez de uvas, os cachos do reino deixavam cair sobre a terra diamantes. - Diamantes, diamantes, diamantes, há anos que é só isto - queixava-se o produtor." (TAVARES, 2005, p.30). E quem sabe se trata disto, o produtor, o fabricante, de versos, em Golgona, busca seu estado de distinição dos diamantes lusitanos por de algum modo voltar às uvas.

Contudo, o fato de se ser ou não compreendido como brilhante, como "consumível no reino", ou como valor de representação do social, na situação de função-autor, pouco importa. Agora, o que temos jamais seria exatamente uma crítica socialista (queiroziana) às classes na cidade, o ressentimento antiburguês, ou uma crítica cesariana-baudelariana à estatura geográfica que dessubjetivasse o sujeito europeu. A autora reivindica o 
realismo, mas não se trata, também, de uma ação contra o conservantismo de seu tempo ou alguma teocracia estética, prenunciando o fim da própria poesia, tal como Antero preconizava na questão coimbrã com seu espírito epidermicamente iconoclástico. E sim, muito paradoxal, dizendo se inspirar nos realistas, temos a poesia de Golgona como efeito da contradição da revolta no presente, a impossibilidade da vanguarda, do drama anteriano ${ }^{14}$, cesariano, a impossibilidade do retorno hegeliano ao realismo hiperprosaico lusitano. O poeta não pode ser fadado a visionário, refutando seu aqui-agora e seu futuro. Uma angústia sem valor numa sociedade onde o pessimismo realista não se contrapõe aos sentimentalismos postiços e que, assim, onde tudo encontra seu espaço, não se procura a si mesma, não se auto-disseca, por meio de um transcendentalismo metafísico ou socialista. Temos a percepção-efeito de um lugar-sem-lugar, sem classe, sem drama, sem destino, o lugar dos escritores de todos os lugares da atualidade, espaço sólido e ao mesmo tempo: não-lugar, escalada líquida. Todo escritor é comercial. Fernando Pessoa, adiante de seu tempo, por exemplo, de modo profético complexificou o lugar clássico do subjetivismo dramático lusitano, com seus heterônimos, produzindo o que a crítica chamou de drama estático. Presentemente, muito após toda possibilidade de drama, um lugar supostamente sentimental da poesia ainda existe em Portugal quando já não haveria mais a opção de poemas lacrimejantes ou autores emotivos. Golgona faz, então, um contorno ao realismo, voltando de algum modo ao passado na argúcia de uma boa observadora do presente. (Uma observadora sensível?)

Lugar de anestesia e anamnese, sobretudo, de responsabilidades fixas na relação com os chamados clássicos, nossos velhos referenciais, os autores-heróis que marcaram história. Para a autora que se volta aos clássicos realistas (o império da glória do romance sobre a decadência do gênero poético, coisa que só será perturbada revolucionariamente no surrealismo, por exemplo), paradoxalmente, a glória é assunto de autópsia, voltar-se ao passado, ao já morto, logo, neste mundo, a posteridade se tornou impossível para os poetas do presente. "Alguém se atreve ainda a falar de posteridade? Eu só penso em como regressar à casa” (p.59). Responsabilidades tais que se apagam à medida que tomam o seu lugar a lei da excitação incessante e a acumulação de sensações de consumo (imagéticos, literários, no caso).

Vim porque me falaram de apanhar cerejas

Ou de armas de destruição em massa.

Mas só encontrei cucos e mexericos de feira,

Metralhadoras de plástico, coelhinhos de Pascoa e pulseiras

De lata.

A bordo, alguém falou de justiça

(não, não era o Marx).

A bordo, falavam também de liberdade.

Quanto mais morríamos,

Mais liberdade tínhamos para matar.

Matava porque estavas perto,

Porque os outros ficaram na esquina do supermercado

A falar, a debater o assunto. (ANGHEL, 2011, p.58) 
Ambivalencialmente, o heroísmo poético, ou o fazer funcional-estilístico deste heroísmo, permanece (o apanhar cerejas, o outro lado "do ecrã de nossos plasmas philips”), e isto se dá mesmo quando já não há mais um sítio seguro do porvindouro autor-herói. Só existe o presente e o ilusório dele sucedido. A autora vai, portanto, à direção de uma ausência, uma falha, uma carência, um irrealismo, seu eu-lírico. A autora não se importa, a autora não importa. A autoria é irreal, virtual. Pouco importa.

$\mathrm{O}$ autor muito menos como um bios individual especial do que um foco de produção estilística, tal como já punham os franceses pósestruturalistas (refiro-me a Foucault, há tantos anos, muito próximo ao diagnóstico de Barthes, quando avocava nas palavras beckettianas a frase: "que importa quem fala?" para definir o que é um autor). Assim, a busca de um estilo que apaga a voz ao mesmo tempo em que elucubra as costas, os declives, do presente comprado. Transpoesia. Poética vadia que pouco se importa com o próprio labor. A poesia é apenas um produto, das ruas, das margens, suborno das esquinas. Tudo pode ser vendido, superexposto, logo, a autora veio porque lhe pagavam e ponto. Estamos diante da impossibilidade de sentimento de uma ocidental? Impossibilidade, também, de realismo.

\section{REFERÊNCIAS BIBLIOGRÁFICAS}

AL BERTO. Horto de Incêncio. Lisboa: Assírio \& Alvim, 1997.

ANGHEL, Golgona. Eis-me Acordado Muito Tempo depois de Mim. Vila Nova de Famalicão: Quasi Edições, 2006.

Vim porque me pagavam. Lisboa: Mariposa Azual, 2011.

BAUDELAIRE, Charles. Sobre a Modernidade. Rio de Janeiro: Paz e Terra, 1996.

BAUDRILLARD, Jean, América. Rio de Janeiro: Rocco, 1986.

. A transparência do mal: Ensaio sobre os fenômenos extremos. São Paulo: Papirus, 1990.

Tela total: mito-ironias do virtual e da imagem. Porto Alegre: Sulina, 2005.

BAUMAN, Zygmunt. O mal-estar da pós-modernidade. Trad. Mauro Gama e Cláudia Martinelli Gama. Rio de Janeiro: Jorge Zahar Editor, 1997

COELHO, Jacinto do Prado. A Originalidade da literatura Portuguesa. Lisboa: Ministério da Educação, 1983.

DELEUZE, G. e GUATTARI, F. Kafka. Por uma literatura menor, trad. Júlio Castañon Guimarães, Imago: Rio de Janeiro, 1977.

FOUCAULT, Michel Microfísica do Poder. 14. ed. Rio de Janeiro: Graal, 1999.

A ordem do discurso. Trad. Laura Fraga de Almeida Sampaio, São Paulo: Loyola, 1996. 
GUATTARI, Félix, Caosmose, um novo paradigma estético, trad. Ana Lúcia de Oliveira e Lúcia Cláudia Leão, São Paulo: Ed.34, 2000.

GOMES, Daniel de Oliveira. Dissonâncias de Foucault. São Paulo: Lumme editor, 2012.

INÁCIO, Emerson da Cruz. A Herança Invisível: ecos da 'literatura viva’ na poesia de Al Berto. Manaus: UEA edições, 2013.

MELO E CASTRO, E. M. de. Poesia/ Transpoesia/ repoesia. Alguns tópicos atuais nas poesias brasileiras e portuguesas. Revista USP, São Paulo (36): 116 - 127, Dezembro/Fevereiro. 1997-98. Disponível em: file://C:/ Users/Windows7/Downloads/26990-31394-1-SM.pdf. Acesso em 12 de junho de 2015.

PEREIRA, David Teles. Orquestra Descon-certante. Público, Cultura-Ípsilon, Lisboa. Agosto. 2011. Disponível em: http://www.publico.pt/roteiros/ jornal/livros-22701613 Acesso em 16 de junho 2015.

RIMBAUD, Arthur. Iluminaciones, Buenos Aires: Libertador, 2004.

SASAKI, Leonardo de Barros. Notas sobre a poesia portuguesa da década de 70. O caso de Al Berto. Anuário de Literatura, Florianópolis, v.18, n. 2, 2013.

TAVARES, Gonçalo M. O senhor Brecht. Rio de Janeiro: Casa da Palavra, 2005.

VERDE, Cesário. A Obra poética integral de Cesário Verde (1855-86). Org. Ricardo Daunt. São Paulo: Landy Editora, 2006.

VIRILIO, Paul, Espaço crítico e as Perspectivas do Tempo Real. 2. ed. Trad. Paulo Roberto Pires. São Paulo: Editora 34, 1999.

Recebido para avaliação em 28/0319 Aprovado para publicação em 14/12/19

\section{NOTAS}

1 Daniel de Oliveira Gomes é doutor e mestre em Literatura pela Universidade Federal de Santa Catarina, estando atualmente em estágio pós-doutoral junto à Université Paris Nanterre, França (Centre de Recherches Interdisciplinaires sur le monde Lusophone). Estuda poesia contemporânea lusófona e suas interfaces com filosofia pós-estrutural francesa. Leciona na Pós-graduação em Estudos da Linguagem junto à Universidade Estadual de Ponta Grossa, Brasil, onde é também vinculado como professor associado nos Cursos de Letras, área de Literatura. Autor de: "Dissonâncias de Foucault" (2012, Lumme, São Paulo) e "A poesia do excesso: Rumo às vísceras de Jorge Melícias" (2011, Toda Palavra: Ponta Grossa).

2 “O Sentimento de um Ocidental”, poema muito criticado (sobretudo negativamente na própria era de Cesário Verde, algumas décadas para os fins do século XIX) pintava uma Lisboa em crise ante a modernização, uma cidade não tão cosmopolita quanto o resto das capitais europeias, mas diante de uma desfiguração satírica da modernidade. Lisboa "cinematizada" (como diria Horácio Costa) pelos versos capturadores-relâmpagos de Cesário Verde: suas putas; seus andaimes como gaiolas prendendo carpinteiros-morcegos; a luz artificial produzida à querosene; cidade fria cuja elegância enlatada se conferiria ao preço da fragmentação do sujeito, alvitrando a distância espiritual e a solidão do olhar como a base extemporânea do poeta. As burguesinhas do catolicismo; pós-de-arroz sufocadores; 
o luxo artificial; as tosses das prostitutas noturnas. Vários poetas influenciaram-se por Cesário Verde, a partir mesmo da própria geração Orpheu. Uma inspiração da inquietude, do dinamismo, do cosmopolitismo, que melhor se expressaria, ainda, na fase do futurismo interseccionista de Álvaro de Campos. Mas como hoje, na poesia lusitana da agoridade, estariam cogitados tais temas, sensações, euforias, experimentadas nesta paisagem já pós-utópica do contemporâneo? Para tanto, trazemos Golgona Anghel à cena.

3 "Bordel”, do latim medieval, "bordellum", remete àquilo que "está na borda", palavra oriunda etimologicamente do catalão "bordell" ou, mais especificamente, do francês cujo significado primogênito seria "casa pequena", "vivenda”. Queremos dizer, aqui, que ter a língua como bordel significa não estar totalmente "a bordo" desta língua embora se possa ter o domínio total sobre ela, como no caso de Golgona Anghel, mas também remete a um espaço de estreita intimidade com esta língua e à cultura desta língua, sobretudo literária, o que significa também, contraditoriamente, que se está imersa até o pescoço na subjetividade desta casa onde se vive, desta língua que é sua, desta identidade que também lhe pertence.

4 Referimo-nos, com este neologismo, a uma origem perdida, uma referência meretriz, negativa, porque a poesia de "Vim porque me pagavam" é feita em torno da temática do prostituível, encaminhando simbolicamente ao panorama de uma poesia "perdida", das “esquinas", ou ao menos conscientemente marginal em vários aspectos.

5 “(...) Também Cioran, que ele já vivia há cerca de dez anos em Paris, e que, no entanto, continuava a escrever na língua romena, ele que ao sair de lá havia deixado publicado cinco de seus livros, ele que um dia em Paris, fora tomado de susto ao perceber que gastava o seu tempo a traduzir Mallarmé ao romeno - uma língua que ninguém conhecia, ele que dizia ser esta a sua língua uma língua arcaica, rude, sem nuanças, e eis que então ele começou a escrever em francês, começou a escrever o livro que veio a ser chamado Breviário de composição, ele conta que tinha um amigo que ele muito admirava, um amigo que era de um imenso cuidado para com a língua, um amigo que era como os puristas no seu rigor, e que certo dia, a um café, ele resolveu ler a este amigo umas duas páginas deste que será o seu Breviário da composição, e o que se deu foi que seu amigo tomou de um sono em meio àquela sua leitura. Cioran dirá de si àquela época: 'eu era um meteco’”' (QUEIROZ, 2013, p.189)

6 "À leitura de "Vim porque me pagavam" (Mariposa Azual, 2011) pouco importa que Golgona Anghel tenha nascido na Ilíria Ocidental, como também pouco importa a sua língua materna, e até pouco parecem importar a história e a cultura do seu país, a Roménia. Tudo isto, aparentemente, foi afastado deste livro com uma precisão intencional, à excepção de uns poucos momentos em que se entrevêem algumas referências ao país de origem de Golgona Anghel (ainda que estas surjam quase sempre como um mecanismo de auto-ironia da autora, não mais relevante do que qualquer outro): "Não vou pedir asilo./ Desconheço os avanços/ ou retrocessos económicos do meu país./ Já falei de Drácula que chegue.” (p. 13). Diga-se já agora que, curiosamente, um dos poucos poemas em que se nota que Golgona Anghel é uma poeta estrangeira a escrever em português é o seu "Portugal, dia um de Maio de dois mil e oito", onde a autora se relaciona com este país na segunda pessoa do plural, não conseguindo, apesar disso, estabelecer com ele uma verdadeira comunicação que não pareça algo forjada: "As nossas amantes baratas./ As nossas putas disponíveis - agora, se faz favor./ Os nossos sonhos transatlânticos./ Os nossos hábitos light, soft, ecológicos, se possível" (p. 70). Apesar do que se acabou de dizer, não deixa de ser verdade que é absolutamente central saber que o português não é a sua língua materna e, principalmente, que a sua aproximação ao idioma se fez muito mais pela via literária do que pelo hábito de o ouvir e pela necessidade de o falar." (PEREIRA, 2011, s/p)

7 Obviamente, também o há do cosmopolitismo e o psicologismo moderno (do orfismo e do presencismo) ressoante na obra al bertiana, sendo, por subsequente, sabido que há uma influência, em Al Berto, de Cesário Verde (por sua vez, influência mor dos jovens poetas que, como Pessoa, revolucionaram as primeiras décadas do século XX, tornados códigos máximos da poesia híbrido-vanguardista desde então). Como aponta Štěrbová: "Achamos importante nomear a influência de Cesário Verde na poética al bertiana. Cesário Verde, poeta oitocentista, no Sentimento dum Ocidental critica a Civilização, é o poeta da permanente vertigem e do tédio. É o poeta da cidade, cidade cheia dos tísicos e engomadeiras; podemos conceber a sua poesia, em oposição a Camões, como o anúncio poético do fim do domínio marítimo e da história monumental, com os seus poemas fecha uma época e abre a porta da época da sociedade industrial urbana. As contrariedades que ele observa são precisamente a podridão da Civilização industrial de aquele então no contraste com a passada euforia expansionista. Al Berto dialoga com a poesia de Cesário Verde na poética de Lisboa. Os 
dois poetas escrevem sobre os problemas da cidade, sobre Tejo sujo e infeccioso. Pode-se tratar duma metáfora clara da condição humana, marcada pela doença, quer de tuberculose, quer da Sida. Os dois poetas são obsessionados por Lisboa, mas têm uma visão bastante decadente da cidade: 'Nas nossas ruas, ao anoitecer, Há tal soturnidade, há tal melancolia, Que as sombras, o bulício, o Tejo, a maresia Despertam um desejo absurdo de sofrer. $\mathrm{O}$ céu parece baixo e de neblina, O gás extravasado enjoa-nos, perturba; E os edifícios, com as chaminés, e a turba, Toldam-se duma cor monótona e londrina.' (...) (Cesário Verde: $O$ livro de Cesário Verde, p.94)'. 'da escrita dos inumeráveis povos quase nada resta - deitas-te exausto na lâmina da lua sem saberes que o tejo te corrói e te suprime de todas as idades da europa mais além - para os lados do corpo - permanece a tosse dos cacilheiros os olhos revirados dos mendigos - o tecto onde um navio nos separa de um vácuo alimentado a soro(...)(Al Berto: O Medo, p.624)” (Štěrbová , 2008, p.18)

8 “Tinha um tique nas asas do nariz. E o vestido chato sobre o peito, curto da roda, tufado pela goma das saias - mostrava um pé pequeno, bonito, muito apertado em botinas de duraque com ponteiras de verniz. Os coletes não estavam prontos, disse com uma voz muito lisboeta; não tivera tempo de os meter em goma. - Tanto lhe recomendei, Juliana! - disse Luísa. - Bem, vá. Veja como se arranja! Os coletes hão de ficar à noite na mala! E apenas ela saiu: - Estou a tomar ódio a esta criatura, Jorge! Há dois meses que a tinha em casa e não se pudera acostumar à sua fealdade, aos seus trejeitos, à maneira aflautada de dizer chapiéu, tisoiras, de arrastar um pouco os rr, ao ruído dos seus tacões que tinham laminazinhas de metal; ao domingo, a cuia, o pretensioso do pé, as luvas de pelica preta arrepiavam-lhe os nervos. - Que antipática! Jorge ria: - Coitada, é uma pobre de Cristo! — E depois que engomadeira admirável!” (QUEIROZ, 1878, p. 870)

$9 \mathrm{O}$ uso de estrangeirismos, sobretudo latino e interjetivo advém já numa influência rimbaudiana em Al Berto.

10 Como aponta a própria autora adotar o realismo: “À mesa,/ Adornada apenas por compoteiras de doce de figo/ Em torno de/ uma travessa de aletria,/ Mato a personagem principal,/ Mas evito formular uma lição social ou moral./ Quero apenas escrever uma hipótese/ E adopto o realismo,/ Porque tem mais leitores./ Não me peçam certificados de qualidade./ Exerço a patologia, não a terapêutica.” (ANGHEL, 2011, p.75)

$11 \mathrm{Ou}$ equivaleria a, falando de outra personagem, um versificar de poeta que sugere a si mesma, usando da alteridade para a desconstituição, assim digamos, de quaisquer impressões iniciais de um pingo que fosse de sacralidade do eu-poeta feminino, como "mocinha da moda" que produziria obras primas pelo tricotar literário. As cedas são, sim, sedutoras e muito práticas, têm seu preço, seu valor realista, dão-nos momentos de prazer, no entanto, possuem uma pretensão de costurar numa pegada clássica (se isto acontece ou não caberá ao seu leitor ajuizar).

12 Alguns versos de Contrariedades: "Eu hoje estou cruel, frenético, exigente;/ Nem posso tolerar os livros mais bizarros./ Incrível! Já fumei três maços de cigarros/ Consecutivamente. (...)/ Sentei-me à secretária. Ali defronte mora/ Uma infeliz, sem peito, os dois pulmões doentes;/ Sofre de faltas de ar, morreram-lhe os parentes/ E engoma para fora.(...)/ O obstáculo estimula, torna-nos perversos;/ Agora sinto-me eu cheio de raivas frias,/ Por causa dum jornal me rejeitar, há dias,/ Um folhetim de versos. (...)/ A crítica segundo o método de Taine/ Ignoram-na. Juntei numa fogueira imensa/ Muitíssimos papéis inéditos. A Imprensa/ Vale um desdém solene./ Receiam que o assinante ingénuo os abandone,/ Se forem publicar tais coisas, tais autores./ Arte? Não lhes convém, visto que os seus leitores/ Deliram por Zaccone. (...)" (VERDE, 2006, s/p.)

13 O negrito é uso da própria autora. O primeiro verso, sempre em negrito, em "Vim porque me pagavam", acaba tornando-se o título de cada poema, ou, ao menos, se se considerar estes não possuindo títulos, viram seu verso referencial, mais destacado.

14 Obviamente que, na dita pós-modernidade, vivemos o clímax de uma sociedade capitalista burocratizada, informatizada, mundializada, etc, e, em termos de poesia, não estamos mais no meio das águas estagnadas da vida da geração de 60 do oitocentismo lusitano, como diria José-Augusto França. Logo, há um abismo de fatos históricos da Coimbra em modernização da velha Sociedade do Raio até aqui. No entanto, posto que Golgona vai ao realismo para encontrar outras fórmulas afirmativas sobre sua geração, atualmente convulsionada por fatores mais complexos do capitalismo, não deixa de ser interessante remeter a canônicos jovens socialistas altamente desmistificadores (escritores que, seguramente, alimentaram os ídolos da poetisa em questão). 